\title{
PERTIMBANGAN HAKIM \\ DALAM MEMUTUS PERKARA PERMOHONAN DISPENSASI KAWIN DI PENGADILAN AGAMA BOJONEGORO
}

\author{
Gunawan Hadi Purwanto \\ Fakultas Hukum, Universitas Bojonegoro \\ e-mail: gunawanhadipurwanto565@gmail.com
}

\begin{abstract}
ABSTRAK
Dispensasi kawin merupakan sebuah tahapan dalam perkawinan yang mana calon mempelai laki-laki ataupun perempuannya masih di bawah umur dan belum diperbolehkan untuk menikah sesuai dengan ketentuan Pasal 7 ayat 1 Undang-Undang Nomor 16 Tahun 2019 tentang Perubahan atas Undang-Undang Nomor 1 Tahun 1974 tentang Perkawinan. Penelitian ini menggunakan metode penelitian empiris dan pengumpulan data dengan wawancara serta membahas 2 (dua) rumusan masalah dengan kesimpulan: bahwa syarat permohonan dispensasi kawin yaitu Surat Permohonan, Fotokopi Kartu Tanda Penduduk kedua orang tua/Wali, Fotokopi Kartu Keluarga, Fotokopi Kartu Tanda Penduduk atau Kartu Identitas Anak dan/atau akta kelahiran Anak, Fotokopi Kartu Tanda Penduduk atau Kartu Identitas Anak dan/atau akta kelahiran Anak calon suami/istri, Foto kopi ijazah pendidikan terakhir anak dan/atau Surat Keterangan Masih Sekolah dari sekolah Anak, Fotokopi surat penolakan dari Kantor Urusan Agama setempat (N9), Fotokopi Surat Keterangan dari Dokter bagi Pemohon Perempuan, Fotokopi surat rekomendasi dari Komisi Perlindungan Anak Daerah Kabupaten Bojonegoro. Serta pertimbangan hakim bahwa meskipun anak kandung para Pemohon dari segi usianya belum cukup umur, namun dilihat secara fisik dan cara berfikirnya ternyata cukup pantas melakukan pernikahan bahkan dilihat dari segi hubungan dengan calon isterinya yang sudah demikian erat dan dapat menghawatirkan akan melakukan perbuatan dosa (zina) yang berkepanjangan, maka untuk menghindarkan mafsadat yang akan timbul dan akan lebih maslahah bagi keluarganya serta untuk kepentingan hukum anak yang berada di dalam kandungan calon mempelai perempuan.
\end{abstract}

Kata Kunci: Pertimbangan Hakim, Dispensasi Kawin 2

\section{PENDAHULUAN}

Menurut Drs. M. Nur Wachid bahwa

Dispensasi kawin adalah sebuah

tahapan dalam hal perkawinan yang

calon mempelai laki-laki ataupun

perempuannya masih di bawah umur

dan belum diperbolehkan untuk

menikah sesuai dengan ketentuan

Pasal 7 ayat 1 Undang-Undang Nomor

16 Tahun 2019 tentang Perubahan atas

Undang-Undang Nomor 1 Tahun 1974

tentang Perkawinan (Selanjutnya

disebut dengan Perubahan UU
Perkawinan). Pemberian batasan

minimal usia perkawinan pada dasarnya bukan tanpa tujuan, tidak lain bahwa pembatasan usia tersebut mengandung maksud agar suatu perkawinan benar-benar dilakukan oleh calon mempelai baik pria maupun wanita yang sudah matang jiwa dan raganya. Hal ini juga mengandung maksud yang lebih jauh, yaitu agar perkawinan itu sendiri dapat mewujudkan tujuan perkawinan dengan tangguh dan harmonis 
berdasarkan Ketuhanan Yang Maha Diharapkan juga kenaikan batas umur Esa. ${ }^{1}$

yang lebih tinggi dari 16 (enam belas)

Pasal 7 ayat (1) Perubahan UU tahun bagi wanita untuk kawin akan

Perkawinan menyatakan bahwa:

mengakibatkan laju kelahiran yang

1. Perkawinan hanya diizinkan apabila pria dan wanita sudah mencapai umur 19 (sembilan belas) tahun.

2. Dalam hal terjadi penyimpangan terhadap

ketentuan umur sebagaimana dimaksud pada ayat (1), orang tua pihak pria dan/atau orang tua pihak wanita dapat meminta dispensasi kepada Pengadilan dengan alasan sangat mendesak disertai buktibukti pendukung yang cukup.

Perubahan norma dalam lebih rendah dan menurunkan resiko kematian ibu dan anak. Selain itu juga dapat terpenuhinya hak-hak anak sehingga mengoptimalkan tumbuh kembang anak termasuk pendampingan orang tua serta memberikan akses anak terhadap pendidikan setinggi mungkin. 2

2 Penjelasan Undang-Undang Nomor 16 Tahun 2019 tentang Perubahan atas Undang-Undang Nomor 1 Tahun 1974 Undang-Undang Nomor 1 Tahun 1974 tentang Perkawinan ini menjangkau batas usia untuk melakukan perkawinan, perbaikan norma menjangkau dengan menaikkan batas minimal umur perkawinan bagi wanita. Dalam hal ini batas minimal umur perkawinan bagi wanita dipersamakan dengan batas minimal umur perkawinan bagi pria, yaitu 19 (sembilan belas) tahun. Batas usia dimaksud dinilai telah matang jiwa raganya untuk dapat melangsungkan perkawinan agar dapat mewujudkan tujuan perkawinan secara baik tanpa berakhir pada perceraian dan mendapat keturunan yang sehat dan berkualitas.

\footnotetext{
${ }^{1}$ Wawancara dengan Bapak Drs. M. Nur Wachid selaku Panitera Muda Bidang Hukum Pengadilan Agama Bojonegoro pada tanggal 28 Oktober 2019
}

2 Penjelasan Undang-Undang Nomor 16 Tahun 2019 tentang Perubahan atas UndangUndang Nomor 1 Tahun 1974 tentang Perkawinan

Pasal 7 ayat (2) Perubahan UU Perkawinan, sehingga Pemberian dispensasi usia perkawinan yang beragama Islam yang belum mencapai batas usia minimal, mengajukan permohonan kepada Pengadilan Agama. $^{2}$ 
Permohonan dispensasi usia akibat kurangnya pengawasan orang perkawinan yang telah didaftar sebagai tua, atau akibat dari kegagalan permohonan maka Panitera akan pendidikan atau akbiat kemajuan membuat daftar sidang, hakim akan teknologi informasi, atau akibat menerima dan memutus dengan menurunnya peran para tokoh agama, membuat penetapan untuk atau bahkan akibat keberhasilan mengabulkan atau menolak pembangunan. Terlepas dari permohonan dispensasi usia permohonan dispensasi kawin yang perkawinan. Dalam memeriksa disertai dengan tengah hamilnya calon perkara tersebut setiap hakim memiliki mempelai perempuan yang masih di pendapat masing-masing (integritas) bawah umur dan calon mempelai lakidalam memutus setiap perkara. Hal laki juga dalam keadaan di bawah tersebut terjadi karena di satu sisi, umur dan masih belum bekerja namun Pengadilan harus tetap menjaga tetap mengajukan kehendak maksud undang-undang, yaitu agar perkawinan maka akan diterbitkan tidak terjadi perkawinan dini dengan surat penolakan dari Kantor Urusan segala akibat buruk yang ditimbulkan. Agama.

Di sisi lain, pengadilan harus tetap Setiap kehendak perkawinan harus melihat kasus tidak hanya dari sisi didaftarkan di KUA dan Pendaftaran kemanusiaan bagi calon mempelai kehendak perkawinan dilakukan yang harus menanggung aib apabila secara tertulis dengan mengisi formulir karena telah hamil tanpa harus ada pendaftaran dan melampirkan yang bertanggung jawab, melainkan beberapa persyaratan sebagaimana juga dari kepentingan si bayi. ketentuan Pasal 4 Peraturan Menteri Perlindungan yang paling berharga, di Agama No. 19 Tahun 2018 tentang samping perlindungan-perlindungan Pencatatan Perkawinan, yaitu :

lain adalah perlindungan hukum, yaitu adanya pengakuan secara hukum, bahwa anak tersebut lahir ke dunia sebagai anak sah yang mempunyai hak-hak secara penuh baik dari ibu dan ayahnya.

Banyak dugaan bahwa hamil di luar nikah adalah akibat pergaulan mudamudi yang semakin meningkat atau

a. Surat pengantar perkawinan dari kelurahan tempat tinggal calon pengantin;

b. Fotokopi akta kelahiran;

c. Fotokopi kartu tanda penduduk;

d. Fotokopi kartu keluarga;

e. Surat rekomendasi perkawinan dari KUA Kecamatan 
setempat bagi calon pengantin yang menikah di luar wilayah kecamatan tempat tinggalnya;

f. Persetujuan kedua calon pengantin;

g. Izin tertulis orang tua atau wali bagi calon pengantin yang belum mencapai usia 21 (dua puluh satu) tahun;

h. Izin dari wali yang memelihara atau keluarga yang mempunyai hubungan darah, dalam hal kedua meninggal dunia atau dalam keadaaan tidak mampu;

i. Izin dari pengadilan, dalam hal orang tua, wali, dan pengampu tidak ada;

j. orang tua atau wali sebagaimana dimaksud dalam huruf (g) j. Dispensasi dari pengadilan bagi calon suami yang belum mencapai umur 19 (sembilan belas) tahun dan bagi calon istri yang belum mencapai umur 16 (enam belas) tahun;

k. Surat izin dari atasannya/kesatuannya jika calon mempelai anggota tentara nasional Indonesia/kepolisian Republik Indonesia;

1. Penetapan izin poligami dari pengadilan agama bagi suami yang hendak beristri lebih dari seorang;

m. Akta cerai atau kutipan buku pendaftaran talak/buku pendaftaran cerai bagi mereka yang perceraiannya terjadi sebelum berlakunya UndangUndang Nomor 7 Tahun 1989 tentang Peradilan Agama;

n. dan Akta kematian atau surat keterangan kematian suami/istri dibuat oleh lurah/kepala desa atau pejabat setingkat bagi janda/duda ditinggal mati.

Melihat proses dispensasi kawin merupakan bagian yang penting dalam kehidupan masyarakat dan keberadaannya telah dilegalkan oleh peraturan perundang-undangan, sehingga perlu diuraikan secara jelas tentang kepastian hukum supaya mendapatkan ijin kawin atau penetapan dari Pengadilan Agama Bojonegoro bagi anak yang belum memenuhi batas usia minimum untuk kawin 19 (Sembilan belas) tahun dan sekaligus dalam hal ini diduga tengah hamil bagi calon mempelai perempuan. oleh sebab itu peneliti merumuskan judul penelitian ini menjadi: "Pertimbangan Hakim dalam Memutus Perkara Permohonan Dispensasi Kawin di Pengadilan Agama Bojonegoro". 
1) Bagaimanakah syarat dan dan prosedur pengajuan perkara prosedur pengajuan perkara permohonan dispensasi kawin anak di permohonan dispensasi kawin bawah umur di Pengadilan Agama anak di bawah umur di Bojonegoro serta Pertimbangan hakim Pengadilan Agama di Pengadilan Agama Bojonegoro Bojonegoro? dalam memutus perkara permohonan

2) Bagaimanakah pertimbangan hakim di Pengadilan Agama Bojonegoro dalam memutus perkara permohonan dispensasi kawin anak di bawah umur dengan keadaan calon mempelai laki-laki masih di bawah umur belum memiliki pekerjaan dan calon mempelai perempuan masih di bawah umur dalam keadaan hamil? dispensasi kawin anak di bawah umur dengan keadaan calon mempelai lakilaki masih di bawah umur belum memiliki pekerjaan dan calon mempelai perempuan masih di bawah umur dalam keadaan hamil.

Lokasi penelitian digunakan untuk mendapatkan informasi dan bahan hukum yaitu Kantor Pengadilan Agama Bojonegoro.

Metode Pendekatan yang

II. METODE PENELITIAN dipergunakan dalam penelitian ini Jenis metode penelitian yang akan menggunakan pendekatan digunakan dalam penelitian ini adalah konsep, yaitu: Pendekatan yang metode penelitian empiris, artinya beranjak dari pandangan-pandangan mempunyai objek kajian mengenai dan doktrin-doktrin yang berkembang perilaku masyarakat. Perilaku di dalam ilmu hukum, guna masyarakat yang dikaji adalah perilaku menemukan ide-ide yang melahirkan yang timbul akibat berinteraksi dengan pengertian, konsep, dan asas hukum sistem norma yang ada. Interaksi yang relevan, sebagai sandaran dalam tersebut muncul sebagai bentuk reaksi membangun suatu argumentasi hukum masyarakat atas diterapkannya sebuah dalam memecahkan isu hukum yang ketentuan perundangan positif dan bisa pula dilihat dari perilaku masyarakat sebagai bentuk aksi dalam memengaruhi pembentukan sebuah ketentuan hukum positif.

Penelitian ini difokuskan untuk mengetahui dan menganalisis syarat 
dihadapi. 3 Bahan hukum yang digunakan dalam penelitian ini adalah sebagai berikut: 4 Bahan Hukum Primer adalah bahan hukum yang diperoleh melalui hasil penelitian lapangan (field research) atau didapatkan secara langsung di dalam masyarakat. ${ }^{5}$

\section{PEMBAHASAN}

a. Syarat Dan Prosedur Pengajuan Perkara Permohonan Dispensasi Kawin Anak Di Bawah Umur Di Pengadilan Agama Bojonegoro

Untuk setiap orang yang hendak mengajukan permohonan perkara dispensasi kawin di lingkungan Pengadilan Agama Bojonegoro harus melengkapi ketentuan persyaratan yang mengacu pada ketentuan Pasal 5 ayat (1) Peraturan Mahkamah Agung Nomor 05 Tahun 2019 tentang Pedoman Mengadili Permohonan Dispensasi Kawin, adalah sebagai berikut : ${ }^{6}$

\section{Surat Permohonan}

Permohonan yang dimaksud dalam hal ini adalah pihak yang mengajukan permohonan Dispensasi harus menyiapkan/membuat Surat Permohonan perihal Dispensasi Kawin atau seperti Surat Gugatan pada pengajuan sebuah Gugatan yang ditujukan kepada Ketua Pengadilan

\footnotetext{
${ }^{3}$ Peter Mahmud Marzuki, 2009. Penelitian Hukum. Kencana Prenada Media Group: Jakarta, hal. 93

4 Mukti Fajar, Yulianto Achmad, 2017. Dualisme Penelitian Hukum Normatif dan Empiris, Pustaka Pelajar
}

Agama Bojonegoro. Dalam surat permohonan tersebut setidaknya memuat identitas kedua orangtua dari anak yang kurang umur yang akan melangsungkan perkawinan dan kemudian dilengkapi dengan alasanalasan hukum mengapa diajukannya permohonan Dispensasi Kawin berikut dengan identitas calon mempelai baik anak dari pemohonmaupun calon suami/isteri anak Pemohon. Perihal surat permohonan apabila Pemohon tidak sanggup membuat, Pengadilan Agama Bojonegoro telah menyediakan Pos Bantuan Hukum (Posbakum) melalui anggaran dari DIPA Badilag Mahkamah Agung yang bekerja sama setiap tahunnya dengan Lembaga Bantuan Hukum (LBH) Terakreditasi di Kabupaten Bojonegoro, yang mana Posbakum tersebut memiliki tugas utama memberikan pelayanan pembuatan surat Gugatan/ Permohonan) terhadap Pemohon yang hendak berperkara .

2. Fotokopi Kartu Tanda Penduduk kedua orang tua/Wali.

Sesuai ketentuan Pasal 6 Perma No. 05 Tahun 2019 tentang Pedoman mengadili Permohonan Dispensasi Kawin, adalah:

a. Bahwa pihak yang berhak mengajukan permohonan Dispensasi Kawin adalah Orang Tua (KTP Kedua Orang Tua).

b. Dalam hal Orang Tua telah bercerai, permohonan Dispensasi Kawin tetap diajukan oleh kedua Orang Tua atau oleh salah satu Orang Tua yang memiliki kuasa asuh terhadap Anak berdasarkan putusan Pengadilan.

c. Dalam hal salah satu Orang Tua telah meninggal dunia atau tidak diketahui keberadaannya

\footnotetext{
${ }^{5}$ Ibid.

${ }^{6}$ Wawancara dengan Drs. M. Nur Wachid selaku Panitera Muda bidang Hukum Pengadilan Agama Bojonegoro
} 
permohonan Dispensasi Kawin diajukan oleh salah satu Orang Tua.

d. Dalam hal kedua Orang Tua telah meninggal dunia atau dicabut kekuasaannya atau tidak diketahui keberadaannya, permohonan Dispensasi Kawin diajukan oleh Wali Anak.

e. Dalam hal Orang Tua/Wali berhalangan, diajukan oleh kuasa berdasarkan surat kuasa dari Orang Tua/Wali sesuai peraturan perundang-undangan.

\section{Fotokopi Kartu Keluarga}

Sebagai pendukung data di atas bahwa Pemohon benar-benar merupakan orang tua atau ada hubungan darah dengan calon yang diajukan dispensasi kawin, selain data berupa Akta Kelahiran. Selain itu untuk Kartu Keluarga juga akan mempermudah dan memastikan namanama orangtua dari Pemohon yang mudah diketahui ketika diperlihatkan dalam Kartu Keluarga.

4. Fotokopi Kartu Tanda Penduduk atau Kartu Identitas Anak dan/atau akta kelahiran Anak Untuk memastikan kesesuaian data identitas calon mempelai perkawinan yang masih kurang umur mulai dari detil nama dan tempat tanggal lahir dengan identitas pada dokumen lain maka harus dilampirkan identitas kependudukan berupa KTP ataupun KIA apabila masih terkategori sebagai seorang anak dan dilengkapi dengan Akta Kelahiran Anak.

5. Fotokopi Kartu Tanda Penduduk atau Kartu Identitas Anak dan/atau akta kelahiran Anak calon suami/istri baik pihak calon mempelai suami atau istri yang masih kurang umur harus melampirkan dokumen KTP ataupun KIA apabila masih seorang anak berikut dengan dokumen Akta Kelahiran, yang memiliki fungsi sama seperti dokumen pada anak Pemohon yaitu untuk memastikan kesesuaian data identitas calon mempelai perkawinan yang bs masih kurang umur mulai dari detil nama dan tempat tanggal lahir dengan identitas pada dokumen lain

6. Foto kopi ijazah pendidikan terakhir anak dan/atau Surat Keterangan Masih Sekolah dari sekolah Anak

Dokumen ijazah ini sangat penting bagi anak Pemohon yang masih kurang umur, untuk menyelaraskan antara keterangan yang disampaikan oleh orang tua pemohon mengenai pendidikan terakhir anak pemohon kepada petugas pembuat permohonan yang ada di Pengadilan Agama. Selain itu Ijazah dijadikan pedoman utama apabila muncul perbedaan ejaan nama dari anak Pemohon yang akan kawin maka nama yang akan dijadikan dasar pengajuan Dispensasi Kawin adalah nama yang tercantum pada Ijazah anak.

7. Fotokopi surat penolakan dari Kantor Urusan Agama setempat (N9). Surat penolakan tersebut merupakan bukti otentik yang dikeluarkan oleh Kantor Urusan Agama di wilayah kecamatan tempat tinggal Pemohon yang mana isi dari pada penolakan tersebut merupakan dasar bagi orang tua pemohon untuk mengajukan permohonan dispensasi kawin di Pengadilan Agama. Surat penolakan tersebut berisi ketentuan bahwa anak yang bersangkutan belum cukup umur sesuai ketentuan di dalam pasal 7 ayat (1) Undang-Undang Nomor 16 Tahun 2019 tentang Perubahan atas UndangUndang Nomor 1 Tahun 1974 tentang Perkawinan, yang menjelaskan bahwa ketentuan dapat dilangsungkannya suatu perkawinan apabila calon mempelai laki-laki dan perempuan sama-sama telah berusia 19 tahun.

8. Fotokopi Surat Keterangan dari Dokter bagi Pemohon Perempuan (Berikut yang Asli dilampirkan) Ketentuan surat keterangan dari Dokter ini diwajibkan apabila yang diajukan Dispensasi oleh Orang Tua Pemohon adalah anak perempuan sekaligus sebagai calon mempelai 
perempuan, yang mana ketentuan persyaratan ini bersifat wajib dilampirkan sebagai bukti otentik hasil pemeriksaan dari Dokter tentang kondisi kandungan calon mempelai perempuan yang sekurang-kurangnya telah menganalisis keadaan dan kesiapan kandungan calon mempelai perempuan ketika melahirkan seorang bayi pada usia anak, sehingga dapat mencegah resiko-resiko kematian yang kemungkinan dapat terjadi baik terhadap seorang ibu maupun calon bayi.

9. Fotokopi surat rekomendasi dari Komisi Perlindungan Anak Daerah Kabupaten Bojonegoro (Berikut yang Asli dilampirkan) Rekomendasi oleh Komisi Perlindungan Anak Indonesia (P3A Kabupaten Bojonegoro meliputi serangkaian proses yang secara teknis memeriksa beberapa aspek mliputi kesiapan terhadap calon pengantin yang diajukan permohonan dispensasi kawin, sehingga layak diberikan rekomendasi walaupun dalam keadaan usia anak namun dari aspek kesiapan sikap dan mental yang baik, maka Badan P3A Kabupaten Bojonegoro akan menerbitkan surat rekomendasi untuk memperkenankan anak usia dini melangsungkan perkawinan.

b. Pertimbangan hakim dalam memutus perkara permohonan dispensasi kawin anak di bawah umur dengan keadaan calon mempelai laki-laki masih di bawah umur belum memiliki pekerjaan dan calon mempelai perempuan masih di bawah umur dalam keadaan hamil di Pengadilan Agama

\section{Bojonegoro}

Perihal keadaan calon mempelai yang diajukan dalam permohonan dispensasi kawin ini dengan keadaan calon mempelai laki-laki masih berada di bawah umur tidak memiliki pekerjaan dan calon mempelai perempuan juga di bawah umur yang sekaligus dalam keadaan hamil (mengandung) anak dari hasil hubungan dengan calon mempelai laki-laki dan menurut ketentuan hukum yang diatur dalam Kompilasi Hukum Islam (KHI) seorang laki-laki dapat mengawini perempuan tersebut. Sebagaimana uraian pada Pasal 53 ayat (1) KHI, yaitu: Perkawinan wanita yang hamil di luar nikah dengan pria yang menghamilinya dapat dilangsungkan tanpa menunggu lebih dahulu kelahiran anaknya.

Drs. Syamsul Azis selaku Wakil Ketua Pengadilan Agama Bojonegoro memberikan jawaban secara sederhana apabila terdapat perkara dispensasi kawin dengan klausul calon pengantin sama-sama berada di bawah umur, tidak bekerja dan calon pengantin perempuan tengah hamil/mengandung seorang bayi, dengan pertimbangan sebagai berikut:

1. Belum Memiliki Pekerjaan sekaligus Masih berada di Bawah Umur

Pekerjaan ini dapat diatasi dengan kesungguhan kedua calon mempelai untuk berkomitmen walupun keduanya sama-sama belum memiliki pekerjaan, namun dengan komitmen kuat tersebut 
akan bersama-sama memulai kehidupan berumah tangga dari bawah. Apalagi kedua orangtua dari calon mempelai memungkinkan untuk tetap membantu perekonomian rumah tangga atau bahkan memberikan modal usaha agar tetap produktif dan mampu mempertahankan rumah tangga dengan baik.

2. Calon Pengantin Perempuan tengah Hamil

Persoalan mendasar inilah yang menjadi pertimbangan secara khusus oleh para Hakim dalam mengadili perkara permohonan Dispensasi Kawin. Di mana dengan keadaan seperti ini Drs. Syamsul Azis, MH memiliki dasar pertimbangan hukum yang kuat bahwa dengan keadaan calon pengantin perempuan masih di bawah umur namun telah hamil maka prinsip perlindungan anak terhadap anak yang dikandung inilah yang akan menjadi dasar utama bahwa demi kepentingan hukum si anak yang masih dalam kandungan yang wajib dilindungi secara hati nurani. Beliau mengilustrasikan bahwa seandainya si anak yang masih dalam kandungan tersebut dapat memilih antara dilahirkan dalam sebuah perkawinan yang sah atau tidak, tentu akan memilih dilahirkan dalam sebuah keluarga yang lengkap terdiri dari bapak dan ibu yang terikat dalam perkawinan yang sah menurut agama dan hukum Negara Indonesia. Namun karena seorang anak yang masih dalam kandungan tersebut tidak dapat memilih hal tersebut akhirnya Hakim berpendapat demi kepentingan hukum seorang anak yang dikandung di luar perkawinan, maka permohonan dispensasi tersebut dikabulkan dan bukan semata-mata melegalkan perzinahan. Apalagi kedua orangtua yang belum terikat perkawinan dari anak yang masih dalam kandungan tersebut secara hukum agama masih memiliki kesempatan untuk bertaubat dan meminta ampunan atas perbuatan yang telah dilakukan, sedangkan anak yang dalam kandungan tidak tahu menahu tentang kehidupan di dunia dan akan lebih sengsara dan menyedihkan apabila dilahirkan tanpa adanya seorang bapak dan ibu dalam perkawinan sah secara hukum Negara

\section{KESIMPULAN}

1. Bahwa syarat dan prosedur pengajuan permohonan dispensasi kawin di Pengadilan Agama Bojonegoro adalah sebagai berikut:

a. Surat Permohonan;

b. Fotokopi Kartu Tanda Penduduk kedua orang tua/Wali;

c. Fotokopi Kartu Keluarga;

d. Fotokopi Kartu Tanda Penduduk atau Kartu Identitas Anak dan/atau akta kelahiran Anak;

e. Fotokopi Kartu Tanda Penduduk atau Kartu Identitas Anak dan/atau akta kelahiran Anak calon suami/istri; 
f. Foto kopi ijazah pendidikan terakhir anak dan/atau Surat Keterangan Masih Sekolah dari sekolah Anak;

g. Fotokopi surat penolakan dari Kantor Urusan Agama setempat (N9);

h. Fotokopi Surat Keterangan dari Dokter bagi Pemohon Perempuan (Berikut yang Asli dilampirkan);

i. Fotokopi surat rekomendasi dari Komisi Perlindungan Anak Daerah Kabupaten Bojonegoro (Berikut yang Asli dilampirkan);

Setelah beberapa persyaratanpersyaratan tersebut dilengkapi oleh para Pemohon, maka proses berikutnya adalah memasukkan pengajuan berkas pendaftaran pada petugas Meja I bagian pendaftaran. Dengan tata urutan prosedur yang telah ditetapkan oleh Pengadilan Agama Bojonegoro tentang Pedoman dalam mengajukan pendaftaran permohonan maupun gugatan, maka segala proses tersebut dapat digambarkan dengan alur proses pengajuan perkara dalam bagan, sebagai berikut:

2. Bahwa pertimbangan Hakim Pengadilan Agama Bojonegoro dalam memutus perkara Dispensasi Kawin dengan ketentuan kedua calon mempelai masih dibawah umur, tidak memiliki pekerjaan dan calon mempelai perempuan sedang hamil, adalah sebagai berikut:

a. Perkawinan yang domohonkan dispensasi akan dilaksanakan di Kantor Urusan Agama Kecamatan Tambakrejo Kabupaten Bojonegoro;

b. Majelis Hakim telah berusaha menasehati Pemohon agar mengurungkan niatnya dalam mengajukan dispensasi kawin dan menunggu usia anak kandung Pemohon hingga dewasa menurut ketentuan yang berlaku, namun tidak berhasil;

c. Dikhawatirkan akan terus menerus melakukan perbuatan dilarang oleh agama (perbuatan dosa yang berkepanjangan) apabila tidak segera dinikahkan;

d. Batas minimal usia perkawinan ditetapkan oleh Undang-undang dengan maksud agar calon mempelai mampu menjalani kehidupan rumah tangga secara baik dengan jiwa yang matang;

e. Meskipun anak kandung Pemohon yang bernama Firdaus Listy Andriyati binti Sumari dari segi usianya belum genap 16 tahun (Seblum UU 16 Tahun 2019), namun dilihat secara fisik dan cara berfikirnya ternyata cukup pantas melakukan pernikahan bahkan dilihat dari segi hubungan dengan calon isterinya yang sudah demikian erat dan dapat menghawatirkan akan melakukan perbuatan dosa (zina) yang berkepanjangan, maka untuk menghindarkan mafsadat yang akan timbul dan akan lebih maslahah bagi keluarganya, perlu dilaksanakan perkawinan dengan segera, dan dari sebab calon suami anak Pemohon juga sudah cukup umur, karenanya Majelis Hakim berpendapat bahwa permohonan Pemohon telah memenuhi alasan yang cukup untuk mengesampingkan ketentuan Pasal 7 ayat (1) Undang-undang Nomor 1 tahun 1974 (Sebelum UU No. 
16 Tahun 2019) jo Pasal 15 ayat (1) Kompilasi Hukum Islam, dan berdasarkan pasal 7 ayat (2) Undang-undang Nomor 1 Tahun 1974 (Sebelum UU No. 16 Tahun 2019) perlu memberikan dispensasi kepada anak kandung Pemohon untuk melaksanakan pernikahan dan secara hukum dinyatakan cakap melakukan tindakan hukum pernikahan;

f. Kepentingan hukum anak yang berada di dalam kandungan calon mempelai perempuan.

Sebagai rekomendasi dari penelitian ini adalah;

1. Pengadilan Agama Bojonegoro diharapkan mampu secara optimal menyampaikan secara tegas terhadap para Pemohon yang akan mengajukan permohonan Dispensasi Kawin bahwa seluruh persyaratan yang ditetapkan agar dipenuhi dengan baik pada saat mendaftar agar dalam pelaksanaan persidangan berjalan dengan lancar sekaligus menunjang pembuktian bagi para Pemohon saat persidangan, termasuk kejelasan teknis perngurusan persyaratan pemeriksaan kandungan dan rekomendasi lain dari instansi terkait.

2. Hakim Pengadilan Agama Bojonegoro sudah sangat tepat ketika menerapkan calon mempelai yang sedang hamil dengan alasan demi kepentingan hukum anak yang dikandung, dan diharapkan pemahaman demikian diterapkan oleh seluruh Hakim di Pengadilan Agama Bojonegoro yang berkesempatan memeriksa, mengadili dan memutus perkara permohonan Dispensasi Kawin. 


\section{DAFTAR PUSTAKA}

\section{a. Buku-Buku}

- Amir Syarifuddin, 2004. Hukum Perkawinan Islam di Indonesia. Predana Media Group: Jakarta

- Mukti Fajar, Yulianto Achmad, 2017. Dualisme Penelitian Hukum Normatif dan Empiris, Pustaka Pelajar Cet keIV: Yogyakarta

- Peter Mahmud Marzuki, 2009, Penelitian Hukum. Kencana Prenada Media Group: Jakarta

\section{b. Wawancara}

- Wawancara dengan Bapak Drs. M. Nur Wachid selaku Panitera Muda Bidang Hukum Pengadilan Agama Bojonegoro pada tanggal 28 Oktober 2019

- Wawancara dengan Bapak Drs. Syamsul Azis, MH selaku Wakil Ketua Pengadilan Agama

Bojonegoro pada tanggal 22 November 2019

c. Perundang-Undangan

- Undang-Undang Nomor 1 Tahun 1974 tentang Perkawinan

- Undang-Undang Nomor 7 Tahun 1989 tentang Peradilan Agama

- Undang-Undang Nomor 3 Tahun 2006 tentang Perubahan atas UndangUndang Nomor 7 Tahun 1989 tentang Peradilan Agama

- Undang-Undang Nomor 16 Tahun 2019 tentang Perubahan atas UndangUndang Nomor 1 Tahun 1974 tentang Perkawinan

\section{c. Jurnal Hukum}

- Tengku Erwinsyahbana, 2012. Sistem Hukum Perkawinan pada Negara Hukum Berdasarkan Pancasila, Jurnal Ilmu Hukum, Volume 2 No. 2

\section{d. Website}

- Cahya Anima Putra, Analisis Dasar Pertimbangan Hakim dalam Menjatuhkan Sanksi Pidana Tindak Pidana Perbuatan Tidak Menyenangkan, http://digilib.unila.ac.id

- Zulfan Law, Dasar Pertimbangan Hakim dalam Menjatuhkan Putusan
Batal Demi Hukum, https://zulfanlaw.wordpress.com/2008 /07/10/dasar-pertimbangan-hakimdalam-menjatuhkan-putusan-bebasdemi-hukum 